\title{
Growth and Yield of Carrot (Daucuscarota L.) as Affected by Different Irrigation Frequency, Organic Soil Amendments and Inorganic Fertilizer
}

\author{
Remedios R. Anub \\ College of Agriculture, Mindanao State University Main Campus, \\ Marawi City
}

\begin{abstract}
Growth and yield of carrots exposed to different irrigation frequency, organic soil amendments and inorganic fertilizer was investigated using $2 \times 4$ factorial experiment designs to find out the effects of those variables. The frequency of irrigation were two (F1) and four days intervals (F2), and the different organic soil amendments were the mushroom spent, chicken dung and native sunflower leaves. The inorganic fertilizer was the ammonium phosphate, urea and muriate of potash (S0). Statistical analysis showed that he length of leaves at 31, 38, 52, 66, 80 and 88 days after emergence and irrigated 2 days interval was highly significant, but the number of leaves, diameter of root, and texture of root were not significant. The root length, weight and number of marketable root, were significantly affected by irrigation at two days interval with the highest yield of $22.06 \mathrm{t} / \mathrm{ha}$, and irrigation at four days interval resulted to lowest yield of 13.84 tons/ha. While no significant interaction were noted on the effects of the two factors on the length of foliage at different days after sowing.
\end{abstract}

Keywords: irrigation frequency, soil amendment, inorganic fertilizer, return on investment.

\section{Introduction}

Carrot (Daucuscarota L.) is one of the most important crops not only in the Philippines but in other countries as well. This crop is a winter crop that is cultivated all over the world for human consumption and feeds for animals. This specie belongs to the family Apiaceae and usually cultivated annually particularly in the tropics region (De Lannoy, 2001). This crop is also affected with season and its quality is based on the length, shape and color of it roots. The best suited environmental temperature of this crop is between $60^{\circ}$ and $70^{\circ} \mathrm{F}$ in which it can produce large root at first growing season and after a prolonged cold period approximately below $45^{\circ} \mathrm{F}$ (Seaman, 2016).The carrot is a root vegetablethat contains different nutrients that have health benefits. This is also good for the eye because of its rich content of beta-carotene. Other beneficial elements in the carrot roots are high fiver content, vitamin K, potassium, and antioxidants (Bjanadottir, 2015).

Growing these crops needs suitable management by providing appropriate amount fertilizer, and water. Rose (2008) pointed out that crops management particularly carrots soil fertility is very important in order to support healthy plant growth. Furthermore, soil type such as sandy soils, sandy loam and silted loam are traditionally considered the best soils for carrots. When soil type is not appropriate for carrots it may resulted to a warped or stunted crops. Moreover, it is also important to consider the soil amendment when it comes to carrot farming. This kind of soil has high nutrient content in such a way that it is mixed with composts or animal manure. Using this can be a productive strategy for building organic matter, biological activity and soil nutrient levels (Seaman, 2016). Amending sandy soils will increase the soil's ability in storing nutrients, and holding moisture. It is also important to note that in doing soil amendments can be done through proper techniques such as decomposed composts, peat, or aged manures are the most appropriate materials. 
On the other hand, fibrous amendments like peat, wood chips, tree park and straw can be also used particularly in clay soils. This will promote aggregation, aeration, porosity, permeability and drainage (Davis et al. 2013). Aside from soil, other important factor to consider in carrot farming is water management efficiency. Ardield et al., (2011) said that management techniques will influence sustainable agriculture. Rose (2008) mentioned that carrots need regular watering in appropriate timing.

\section{Methods}

\section{Design}

Research design used in the study was experimental research design employing a $2 \times 4$ factorial experiment through Randomized Complete Block Design (RCBD). Factor F are two irrigation frequency (F1 and F2), and factor $\mathrm{S}$ are source of organic soil amendments combined with inorganic fertilizer (S0, S1, S2 and S3).

\section{Location}

Experimental research on the effects of different irrigation frequency, organic soil amendments and inorganic fertilizer on the growth and yield of carrot was conducted the farm area in the College of Agriculture, Mindanao State University, Marawi City, Lanaodel Sur province, Philippines from July 10, 2004 to November 18, 2004. LanaoDel Sur provincehad a tropical climate and had significant rainfall throughout the period of study with an average rainfall of $7.10 \mathrm{~mm}$ while maximum temperature was $28.10^{\circ} \mathrm{C}$.

\section{Procedure}

The experimental area of 100 square meters and subdivided into three blocks that represents for three replications.Each replication consists of eight plots measuring one meter by two meters and distance between plots and blocks was 0.5 meter and between block was also 0.5 meter. Factor F was frequency of irrigationand F1, the irrigation was at two days interval and F2, the irrigation was at four days interval. All plots were covered with plastic sheets to avoid bias and plots were in raised beds form and drainage canal was constructed to drain the water during rainy days. Factor $\mathrm{S}$ were the organic soil amendments combined with the same kind of inorganic fertilizers. The S0 was the control with no soil amendments, the S1 was the mmushroom spent, the S2 was the cchicken dung and S3 was the sunflower leaves. The soil amendments were applied one month before planting at 20 $\mathrm{kg}$ per square meter while inorganic fertilizer was also applied during planting following the recommended rate of 30-20-60 kg NPK/hectare.

Table 1: Data on rainfall and temperature from a period of July 2004 to November 2004

\begin{tabular}{|c|c|c|c|c|}
\hline \multirow{2}{*}{$\begin{array}{l}\text { Period of the } \\
\text { study in month }\end{array}$} & \multirow{2}{*}{$\begin{array}{l}\text { Rainfall } \\
(\mathrm{mm})\end{array}$} & \multicolumn{2}{|c|}{ Air Temperature $\left({ }^{0} \mathrm{C}\right)$} & \multirow{2}{*}{$\begin{array}{l}\text { Relation } \\
\text { Humidity } \\
(\%)\end{array}$} \\
\hline & & $\begin{array}{l}\text { T(maximu } \\
\mathrm{m})\end{array}$ & $\mathrm{T}$ (minimum) & \\
\hline July & 13.63 & 29.32 & 21.40 & 93.77 \\
\hline August & 2.55 & 26.93 & 23.22 & 78.32 \\
\hline September & 12.36 & 30.21 & 22.14 & 99.0 \\
\hline October & 3.83 & 29.16 & 21.72 & 95.45 \\
\hline November & 3.13 & 24.66 & 18.34 & 76.57 \\
\hline
\end{tabular}

Table 2: Soil test results of the experimental area

\begin{tabular}{|c|c|c|c|c|c|c|c|c|}
\hline \multicolumn{5}{|c|}{ SOIL TEST DATA } & CROPS & \multirow{2}{*}{\multicolumn{3}{|c|}{$\begin{array}{l}\text { Nutrient Requirements } \\
\mathrm{Kg} / \mathrm{IIa}\end{array}$}} \\
\hline$\% \mathrm{Ppm}$ & $\overline{\mathrm{pp}}$ & & & ton $/ \mathrm{h}$ & Variety/A & & & \\
\hline $\mathrm{OM}$ & $\mathrm{P}$ & $\mathrm{K}$ & $\mathrm{pH}$ & LIME & & $\mathrm{N}$ & $\mathrm{P}$ & $\mathrm{K}$ \\
\hline 4.2 & 18 & 209 & 5.69 & & Carrot & 30 & 20 & 60 \\
\hline
\end{tabular}

*Regional Soil Testing Laboratory, Department of Agriculture, Region 10, Cagayan de Oro City 
Table 3: General properties of organic soil amendments used in the study

\begin{tabular}{|c|c|c|c|c|c|c|}
\hline \multirow[t]{2}{*}{$\begin{array}{l}\text { CONTENTS } \\
\text { (CONTITUENTS) }\end{array}$} & \multicolumn{2}{|c|}{$\begin{array}{l}\text { MUSHROON } \\
\text { SPENT }\end{array}$} & \multicolumn{2}{|c|}{$\begin{array}{l}\text { CHICKEN } \\
\text { DUNG }\end{array}$} & \multicolumn{2}{|c|}{$\begin{array}{l}\text { WILD } \\
\text { SUNFLOWER } \\
\text { LEAVES }\end{array}$} \\
\hline & $\begin{array}{l}\text { air dry } \\
\text { basis }\end{array}$ & $\begin{array}{l}\text { oven } \\
\text { dry } \\
\text { basis }\end{array}$ & $\begin{array}{l}\text { air dry } \\
\text { basis }\end{array}$ & $\begin{array}{l}\text { oven } \\
\text { dry } \\
\text { basis }\end{array}$ & $\begin{array}{l}\text { air dry } \\
\text { basis }\end{array}$ & $\begin{array}{l}\text { oven } \\
\text { dry } \\
\text { basis }\end{array}$ \\
\hline & $(\%)$ & $(\%)$ & $(\%)$ & $(\%)$ & $(\%)$ & $(\%)$ \\
\hline Total Nitrogen $(\mathrm{N})$ & 2.10 & 2.51 & 2.37 & 2.72 & 1.68 & 1.99 \\
\hline $\begin{array}{l}\text { Total Phosphoric Acid } \\
\text { (P205) }\end{array}$ & 9.16 & 10.97 & 4.58 & 5.26 & 7.33 & 9.27 \\
\hline $\begin{array}{ll}\text { Available } & \text { Phosphoric } \\
\text { Acid (P205) } & \\
\end{array}$ & & & & & & \\
\hline Total Potassium (K205) & 1.94 & 2.32 & 4.84 & 5.56 & 6.78 & 8.02 \\
\hline Calcium Oxide $(\mathrm{CaO})$ & & & & & & \\
\hline $\begin{array}{ll}\text { Calcium } & \text { Carbonate } \\
(\mathrm{CaCO} 3) & \\
\end{array}$ & & & & & & \\
\hline $\begin{array}{ll}\text { Magnesium } & \text { Oxide } \\
(\mathrm{MgO}) & \end{array}$ & & & & & & \\
\hline Moisture Content & & 16.50 & & 13.00 & & 15.5 \\
\hline PH of the sample & & & & & & \\
\hline
\end{tabular}

* Regional Soil Laboratory, department of Agriculture Region 10, Cagayan de Oro City

\section{Results and Discussions}

Ten sample plants taken randomly in every treatment as data plants. The gathered data were recorded, tabulated and statistically analysed using Analysis of Variance (ANOVA) and Ducan's Multiple Range Test (DMR'T).

\section{A. Effects of frequency of irrigation on the growth, yield and yield of carrots}

\section{A.1. Growth parameters}

Growth parameters includes length, and number of leaves develop in the planted carrot. The gathered data on leaves length from six different growth period: a) 31 days after emergence (DAE), 38 (DAE), 52 DAE, 66 DAE, 80 DAE, 88 DAE showed that carrots irrigated at every two days interval produced longer leaves with a mean of $5.60 \mathrm{~cm}(31 \mathrm{DAE}), 10.62 \mathrm{~cm}(38 \mathrm{DAE}), 23.72 \mathrm{~cm}$ (52 DAE), $37.03 \mathrm{~cm}$ (66 DAE), $49.06 \mathrm{~cm}(80 \mathrm{DAE})$ and $52.09 \mathrm{~cm}(88 \mathrm{DAE})$ than carrot irrigated at four days interval with a mean $4.98 \mathrm{~cm}$ (31 DAE), $9.58 \mathrm{~cm}$ (38 DAE), $20.69 \mathrm{~cm}$ (52 DAE), 31.50 $\mathrm{cm}$ (66 DAE), $41.54 \mathrm{~cm}$ (80 DAE) and $44.50 \mathrm{~cm}$ (88 DAE) respectively (Table 4). Based on the results of the study, irrigation frequency did not affect significantly on the length of leaves in all different growth stages of carrots.

In the case of the number of leaves results showed that two days interval of irrigation in carrot plants produced the highest number of leaves with a mean of 9.01, while plants irrigated at four days interval resulted to least number of leaves with a mean of 8.91 (Table 4). However, the two irrigation frequency had no significant effects on the number of leaves of carrots.

\section{A.2. Yield and Yield Components}

Yield and yield components were determined through the diameter of carrot root, length of root, number of marketable root, weight of marketable root, quantity of non-marketable root, weight of non-marketable root and the overall yield. Findings revealed thatthe carrot root diameter exposed to irrigation frequency at two days interval $\left(\mathrm{F}_{1}\right)$ provide exact amount of moisture that made the carrot produced a bigger diameter of $2.02 \mathrm{~cm}$ while plants irrigated every 4 days interval $\left(\mathrm{F}_{2}\right)$ had a smaller diameter of $1.74 \mathrm{~cm}$. Statistically analyzed, the two irrigation frequency did not affect significantly on the development of roots (Table 4).

Length of roots that was irrigated at every 2 days interval $\left(\mathrm{F}_{1}\right)$ produced longer carrot roots $(14.08 \mathrm{~cm})$ and carrot plant irrigated every 4 days interval $(12.64 \mathrm{~cm})$, and the results showed was highly significant (Table 4). This showed that irrigation at two days interval and four days interval 
was sufficient for the carrot root development. Gillespie et al. (2017) stated that minimizing water deficits is crucial for achieving high yields of quality carrots. However, Prince (2018) stated that carrots can tolerate dry conditions however moisture stress needs to be avoided to produce high yield and quality, and the soil quality is also important.

In terms of the number of marketable roots, results showed that treatments F1 (irrigated every 2 days) with a mean of 7.33 has higher marketable roots compared to carrot plant exposed to treatment F2 (irrigated at every 4 interval) which produced lower number of marketable roots with a mean of 5.33 (Table 4). Analysis of variance showed that the result was significant. This result implied that irrigation application had contributed the production of marketable roots. Seljasen et al., (2013) affirmed the findings of this study saying that growth and healthiness of carrot plants are influenced by the availability of water to proper timing and amount. Hamma, et al., (2012) cited the result of Barta and Kallo (1991) stating that one factors to consider in carrot farming is the proper irrigation schedule in order to maximize the crop yields.

The weight of marketable roots was also influence by the frequency of irrigation. irrigation frequency at every 2 days (F1) showed higher mean of 388 gm compared to carrots irrigated at every 4 days with means weight of $211.50 \mathrm{gm}$ (Table 4). Irrigation frequency affects significantly on the weight of marketable roots. The result conformed to the findings of Alamet al., (2010) states that the frequency of irrigation to carrot plants greatly influence on the weight of its marketable roots.

Moreover, findings of this study revealed that the quantity of non-marketable roots of carrots is higher in the treatment exposed to every 4 days (F2) irrigation while carrot plant exposed to irrigation frequency with 2 days interval (F1) produced the lowest with a mean of 2.67 (Table 4). The result showed that irrigation frequency affects significantly on the development of nonmarketable roots.Kemble (2000) said that improper irrigation lead to misshapen split roots in carrots.

In the case of the weight of non-marketable roots of carrots, findings of this study revealed that carrot plants irrigated every 2 days interval (F1) have a mean weight of 59.08 gm and plants irrigated every 4 days (F2) produced only 45.92 gm (Table 4.) Statistically analyzed, the weight of non- marketable roots were highly significant, which means that the two schedule of irrigation were not sufficient of providing exact amount of water for root development. According to Kemble (2000), proper management of root crops is very important in farming particularly carrot species which is very sensitive with the availability and exposure to water. Proper water management in carrot farming is very crucial and it needs and even and abundant water supply all throughout the planting period. Moisture stress can lead to the formation of small, woody, and poorly flavored roots.

For the overall yield of carrot rots (ton/ha), findings of this study disclosed that carrot plants irrigated every 2 days $\left(\mathrm{F}_{1}\right)$ produced the highest mean yield of 22.06 tons/ha while plants irrigated at every 4 days $\left(\mathrm{F}_{2}\right)$ produced the least $(13.84$ tons $/ \mathrm{ha})$. The two irrigation frequencies affects significantly on the yield of carrots at 88 DAS (Table 4).These findings demonstrate that irrigation application could either be done every two days or every four days. According to Ardiles et al., (2011) proper water management is a key to a successful and sustainable agriculture development not only for carrot farming but to other root crops as well. 
Table 4: Independent effects of frequency of irrigation on the length of leaves, number of leaves, diameter of root, length of root, number of marketable root, weight of marketable roots, number of non-marketable root, weight of non-marketable root, and yield of carrot

\begin{tabular}{|l|l|l|}
\hline PARAMETERS & Frequency of Irrigation (mean) \\
\hline 1. Growth parameters & $\begin{array}{l}\text { Two days interval } \\
\text { (F1) }\end{array}$ & $\begin{array}{l}\text { Four days interval } \\
\text { (F2) }\end{array}$ \\
\hline $\begin{array}{l}\text { 1.a. Length of leaves(cm) at different } \\
\text { growth period in number of days after } \\
\text { emergence (DAE) }\end{array}$ & $5.60 \mathrm{~ns}$ & $4.98 \mathrm{~ns}$ \\
\hline 31 & $10.62 \mathrm{~ns}$ & $9.58 \mathrm{~ns}$ \\
\hline 38 & $23.72 \mathrm{~ns}$ & $20.69 \mathrm{~ns}$ \\
\hline 52 & $37.03 \mathrm{~ns}$ & $31.50 \mathrm{~ns}$ \\
\hline 66 & $49.06 \mathrm{~ns}$ & $41.54 \mathrm{~ns}$ \\
\hline 80 & $52.09 \mathrm{~ns}$ & $44.50 \mathrm{~ns}$ \\
\hline 88 & $9.01 \mathrm{~ns}$ & $8.91 \mathrm{~ns}$ \\
\hline 1.b.Number of leaves & & \\
\hline 1. Yield and yield components & $2.02 \mathrm{~ns}$ & $1.74 \mathrm{~ns}$ \\
\hline 2.a.Diameter of root (cm) & $14.08 \mathrm{a}$ & $12.64 \mathrm{~b}$ \\
\hline 2.b.Length of root (cm) & $7.33 \mathrm{a}$ & $5.33 \mathrm{~b}$ \\
\hline 2.c. Number of Marketable root & $388 \mathrm{a}$ & $211.50 \mathrm{~b}$ \\
\hline 2.d. Weight of marketable root $(\mathrm{g})$ & $2.67 \mathrm{~b}$ & $5.17 \mathrm{a}$ \\
\hline $\begin{array}{l}\text { 2.e. Number of non-marketable root } \\
\text { (g) }\end{array}$ & & $45.92 \mathrm{~b}$ \\
\hline 2.f. Weight of non-marketable root (g) & $59.08 \mathrm{a}$ & $13.84 \mathrm{~b}$ \\
\hline 2.g.Yield (ton/ha) & $22.06 \mathrm{a}$ & \\
\hline
\end{tabular}

$*$ Means within a row bearing different letters are significantly different $(\mathrm{P}<0.05)$

ns $=$ not significant

\section{B. Effects of combining organicsoil amendments and inorganic fertilizers to growth and yield of carrot}

\section{B.1. Growth Parameters}

\section{Length of leaves}

Table 5 shows the mean length of leaves in response to treatments. At 31 days after emergence (DAE), the longest leaves were observed in plants applied with mushroom spent with a mean of $8.96 \mathrm{~cm}$, followed by application of chicken dung with $5.75 \mathrm{~cm}$, the sunflower leaves with a mean of $3.67 \mathrm{~cm}$ and the lowest mean was obtained in plants with no organic soil amendments with a mean of $2.94 \mathrm{~cm}$. At 38 days after emergence (DAE), the longest leaves were observed in plants applied with mushroom spent with a mean of $15.74 \mathrm{~cm}$, followed by application of chicken dung with 11.05 $\mathrm{cm}$, the sunflower leaves with a mean of $7.86 \mathrm{~cm}$ and the lowest mean was obtained in plants with no organic soil amendments with a mean of $5.76 \mathrm{~cm}$. In the subsequent number of period of growth at $52 \mathrm{DAE}, 66 \mathrm{DAE}, 80 \mathrm{DAE}$ and $88 \mathrm{DAE}$, the mushroom spent had a highest mean compared to chicken dung and sunflower. Statistically analyzed, the organic soil amendments significantly affect the length of leaves. Table 3 shows the laboratory test results of the different organic soil amendments used in the study. Bonato et al., (2016) emphasized that not all product contents in spent mushroom substrate is organic matter. Jilani et al., (2016) found out that applying organic manures and NPK can improve carrot growth and yield, in which the best to use is poultry manure and goat manure. According to the research study of Babu et al., (2014) that plant residue like sunflower comprises key plant nutrients in ranging from 0.45 to $0.60 \% \mathrm{~N}, 0.15$ to $0.22 \% \mathrm{P}$, and 1.80 to $1.94 \% \mathrm{~K}$ along with secondary and micro-nutrients needed by plants. Plants residue is the best way and practice for replacing the washed-out soil fertility and refining the physical, chemical, and biological properties of the soil. 


\section{Number of leaves}

The data on the leaves quantity was shown in Table 5. It was observed that pplantstreated with mushroom spent $\left(S_{1)}\right.$ had higher numbers of leaves with a mean of 9.6, followed by treatment with no application of soil organic amendments $\left(\mathrm{S}_{0}\right)$ with a mean of 9.12, while chicken dung (S2) had a mean of 9.02 and sunflower $\left(\mathrm{S}_{3}\right)$ had a mean of 8.10. The application of different organic soil amendments did not affects significantly on the number of leaves at 88 DAE.

B.2. Yield and Yield Components

\section{Diameter of root $(\mathrm{cm})$}

Data on diameter of root at 88 DAS is shown in Table 5. As depicted in the data, it shows that fertilizer sources have significant effect on the diameter of root. The mushroom spent $\left(\mathrm{S}_{1}\right)$ produced bigger diameter with a mean of $2.91 \mathrm{~cm}$ followed by treatment with chicken dung $\left(\mathrm{S}_{2}\right)$ with a mean of $2.23 \mathrm{~cm}$, the sunflower leaves $\left(\mathrm{S}_{3}\right)$ had a mean of $1.46 \mathrm{~cm}$ and the lowest mean of 0.91 was in treatments with inorganic fertilizer $\left(\mathrm{S}_{0}\right)$. Jilani et al., (2016) mentioned that organic manures and NPK can improve carrot growth and yield, but the best to use is poultry manure and goat manure. Jeptoo et al., (2013) also mentioned that that application of Tithoniadiversifolia manure will increase the fresh root weight, dry root and shoot biomass and root volume.

\section{Length of root $(\mathrm{cm})$}

Findings of this study revealed that different sources of fertilizers that is applied to the carrot plant significantly affect the length of carrot root. Plants in $\left(\mathrm{S}_{1}\right)$ yielded the highest length with a mean of $14.98 \mathrm{~cm}$ followed by plants $\mathrm{S}_{2}, \mathrm{~S}_{0} \& \mathrm{~S}_{3}$ with corresponding means of $14.85,12.25$ and $11.37 \mathrm{~cm}$ (Table 5). According to Jilani et al., (2016) the application of organic manures and NPK can improved carrot growth and yield, particularly using poultry manure (PM) and goat manure (GM). Similarly, Ceronio et al., (2013) added that chicken manure-treated plants produced more leaves as compared in using compost and kraal manure. Organic fertilizers enhance the growth and yield of carrot.

\section{Number of marketable roots}

Plants in S1 yielded the highest number of marketable roots of 10 pieces, followed by those in $\left(\mathrm{S}_{2}\right),\left(\mathrm{S}_{3}\right)$ and $\left(\mathrm{S}_{0}\right)$,with means of 8.67, 3.67and3.respectively(Table 5). The different fertilizer sources showed significant effect on the number of marketable roots. This finding revealed the benefit derived in utilizing mushroom spent together with urea and muriate of potash. It is highly probable that the nutrient content in mushroom spent is readily available to the plants for its physiological as well as production of uniform size storage root to pass for the grading on marketability.

\section{Weight of marketable roots}

The weight of marketable roots of plants in $\mathrm{S}_{1}$ significantly differed from those in $\mathrm{S}_{2}$ and the latter also significantly differed from $\mathrm{S}_{3} \& \mathrm{~S}_{0}$ as shown in Table 4.0. The actual weight are $\mathrm{S} 1$ with $642.17 \mathrm{~g}$ followed by $\mathrm{S}_{2}(388.67 \mathrm{~g}), \mathrm{S} 3(99 \mathrm{~g})$ and $\mathrm{S}_{0}(69.17 \mathrm{~g})$ in descending order. The weight of marketable roots was significantly affected by the application of the different soil amendment. Organic soil amendments provide benefits to yield of carrots because it contains major plant nutrients. Ceronio et al.,(2013) expressed that organic fertilizer can be beneficial to carrot yield and quality within specific application levels. Findings revealed that organic soil amendments and inorganic fertilizers significantly affect the weight of carrot roots.

\section{Number of non-marketable root}

The carrot plants exposed to inorganic fertilizer $\left(\mathrm{S}_{0}\right)$ had significantly highest number of nonmarketable roots of 7 , followed by $\left(S_{3}\right),\left(S_{2}\right)$ and $\left(S_{1}\right)$ with corresponding mean of $6.33,2.33 \& 0$, respectively (Table 5). Significant effect of the sources of fertilizer applied in the carrot plants to the non-marketable carrot roots was noted. The result indicates that the amount of organic soil amendments applied did not satisfied the nutrients required by the crops and the soil condition also affects the development of quality carrot roots. According to Gran (2018) that carrots need well worked soil with good organic amendments and plenty of water. 


\section{Weight of non-marketable roots}

The mean weight of non-marketable roots at $88 \mathrm{DAE}$ significantly differed. Plants fertilized with inorganic fertilizer $\left(\mathrm{S}_{0}\right)$ has the heaviest weight of $73.67 \mathrm{gm}$ followed by $\left(\mathrm{S}_{3}\right),\left(\mathrm{S}_{2}\right)$ and $\left(\mathrm{S}_{1}\right)$ with the value of $69.17,39.67$ and 27.50 , respectively.

\section{Yield (ton/ha)}

Application of organic soil amendments with an inorganic fertilizer affects significantly the yield of carrot at 88 DAE. Highest yield of $33.48 \mathrm{t}$ was obtained from plants in $S_{1}$ followed by plants in $S_{2}$ with $21.85 \mathrm{t}, \mathrm{S}_{3}$ with $9.0 \mathrm{t}$ and the smallest yield was obtained from plants in $\mathrm{S}_{0}$ of 7.46 ton/ha (Table 5). Sunassee (2002) cited the result of Reddy and Reddi (1995) pointing out that poultry manure is an important source of plant nutrients. As reported by Sunassee (2002), poultry litter contain $30 \%$ of nitrogen which is readily available to plants and using this litter physical property of soil will be improved. Physical properties of soil plays important role in the development of carrot roots and its quality.

Table 5: Mean data on independent effects of combining the organic soil amendments and inorganic fertilizer on carrot growth yield.

\begin{tabular}{|c|c|c|c|c|}
\hline \multirow{2}{*}{$\begin{array}{l}\text { PARAMETERS } \\
\text { 1. Growth }\end{array}$} & \multicolumn{4}{|c|}{$\begin{array}{l}\text { Organic soil amendments and inorganic } \\
\text { fertilizer }\end{array}$} \\
\hline & $\mathrm{SO}$ & S1 & $\mathrm{S} 2$ & S3 \\
\hline \multicolumn{5}{|l|}{$\begin{array}{l}\text { 1.a. Length of leaves }(\mathrm{cm}) \text { at different } \\
\text { growth period in number of days } \\
\text { after emergence (DAE) }\end{array}$} \\
\hline 31 & $2.94 \mathrm{c}$ & $8.96 \mathrm{a}$ & $5.75 \mathrm{~b}$ & $3.67 \mathrm{c}$ \\
\hline 38 & $5.76 \mathrm{c}$ & $15.74 \mathrm{a}$ & $11.05 \mathrm{~b}$ & $7.86 \mathrm{c}$ \\
\hline 52 & $12.84 \mathrm{c}$ & $34.82 \mathrm{a}$ & $25.90 \mathrm{~b}$ & $15.27 \mathrm{c}$ \\
\hline 66 & $21.25 \mathrm{c}$ & $49.45 \mathrm{a}$ & $40.83 \mathrm{~b}$ & $25.53 \mathrm{c}$ \\
\hline 80 & $35.57 \mathrm{~b}$ & $56.40 \mathrm{a}$ & $51.27 \mathrm{a}$ & $37.96 \mathrm{~b}$ \\
\hline 88 & $38.33 \mathrm{~b}$ & $58.88 \mathrm{a}$ & $53.90 \mathrm{a}$ & $42.06 \mathrm{~b}$ \\
\hline 1.b. Number of leaves & $9.12 \mathrm{a}$ & $9.60 \mathrm{a}$ & $9.02 \mathrm{a}$ & $8.10 \mathrm{a}$ \\
\hline \multicolumn{5}{|l|}{ 2. Yield and Yield components } \\
\hline 2.a. Diameter of root $(\mathrm{cm})$ & $0.91 \mathrm{~d}$ & $2.91 \mathrm{a}$ & $2.23 \mathrm{~b}$ & $1.46 \mathrm{c}$ \\
\hline 2.b. Length of root (cm) & $12.25 \mathrm{~b}$ & $14.98 \mathrm{a}$ & $14.85 \mathrm{a}$ & $11.37 \mathrm{~b}$ \\
\hline 2.c. Number of Marketable root & $3.00 \mathrm{~b}$ & $10.00 \mathrm{a}$ & $8.67 \mathrm{a}$ & $3.67 \mathrm{~b}$ \\
\hline 2.d. Weight of marketable root $(\mathrm{g})$ & $69.17 \mathrm{c}$ & $\begin{array}{l}642.17 \\
\mathrm{a}\end{array}$ & $388.67 \mathrm{~b}$ & $99.00 \mathrm{c}$ \\
\hline $\begin{array}{l}\text { 2.e. Number of non-marketable root } \\
\text { (g) }\end{array}$ & $7.00 \mathrm{a}$ & $0.00 \mathrm{c}$ & $2.33 \mathrm{~b}$ & $6.33 \mathrm{a}$ \\
\hline $\begin{array}{l}\text { 2.f. Weight of non-marketable root } \\
\text { (g) }\end{array}$ & $73.67 \mathrm{a}$ & $27.50 \mathrm{~b}$ & $39.67 \mathrm{a}$ & $69.17 \mathrm{a}$ \\
\hline 2.g. Yield (ton/ha) & $7.46 \mathrm{c}$ & $33.48 \mathrm{a}$ & $21.85 \mathrm{~b}$ & $9.00 \mathrm{c}$ \\
\hline
\end{tabular}

$*$ Means within a row bearing different letters are significantly different $(\mathrm{P}<0.05$.)

\section{Interaction Effects of Different Irrigation Frequency and Combined Use Organic Soil Amendments and Inorganic Fertilizers}

\section{C.1. Growth parameters}

\section{Length of leaves}

The findings of this study revealed that the different irrigation frequency and fertilizer used affects the leave length of carrot plants. From the obtained data at 31, 38, 52, 66, 80, and 88 days after sowing (DAE), it was noted that the length of leaves in 31 and $38 \mathrm{DAE}$, were not significantly affected by the frequency of irrigation and application of inorganic fertilizer and organic soil amendments (Table 6). However, in 52, 66, 80 and $88 \mathrm{DAE}$, the length of leaves were significantly affected by frequency of irrigation and combined used of organic soil amendments. In six different period of growth, the longest length of leaves were observed in carrots irrigated at 2 days interval and applied with mushroom spent as organic soil amendments as presented in table 6 . According to 
Neilsen et al., (1998) that the ability of organic waste to release $\mathrm{N}$ slowly is advantageous to plant in absorbing inorganic nitrogen.

\section{Number of leaves}

The data in treatment 6 in which carrots were irrigated at 4 days interval and applied with mushroom spent produced higher number of leaves with a mean of 97.97 , followed by $\mathrm{T} 1$ with a mean of 9.78 , T3 (9.61), T2 (9.23), T8 (8.77), T5 (8.46), T7 (8.43) and the lowest number of leaves was produced in T4 (7.43) as presented in Table 6. It was noticeable that the increased on the number of leaves was significantly affected by the application of organic soil amendments in combination of inorganic fertilizer either irrigated at 2 days or 4 days interval. This showed that the availability of nitrogen, phosphorus and potassium elements in inorganic fertilizer and in all organic soil amendments applied (Table 3) played an important role on the number of leaves and availability of soil moisture is also important. As pointed out by Neilsen et al., (1998), the ability of organic waste to release $\mathrm{N}$ slowly under conditions of frequent irrigation is likely to be advantageous for plant $\mathrm{N}$ uptake relative to single-time inorganic $\mathrm{N}$ fertilizer applications.

C.2. Yield and Yield Components

\section{Diameter of root}

Findings of this study discovered that the irrigation frequency and application of organic soil amendments combined with inorganic fertilizerdoes not significantly affect the diameter of carrot roots at $88 \mathrm{DAE}$ (Table 6). However, the application of mushroom spent and irrigation application at two days interval made the crops produced bigger root diameter compared to chicken dung, sunflower and inorganic fertilizer.

\section{Length of Root}

Irrigation frequency and combined used of organic soil amendments with inorganic fertilizers did not affects significantly to thelength of carrot roots as shown in Table 6. Plants irrigated every two days and applied with mushroom spent had longer length of root (T3) while the shortest was produced by plant irrigated every four days and fertilized with purely inorganic fertilizers (T5).

\section{Number of marketable roots}

The number of marketable roots was also affected by irrigation frequency and different fertilizer sources. Plants treated in T2 and T6 gave the highest number of marketable roots of 10 pieces followed by T3, T7, T1, T8, and T5 with corresponding means of 9, 8.3, 5.33, 5.0, 2.0 and 1.0 respectively (Table 6).The used of mushroom spent contribute significantly to the number of marketable root of carrots. Nutrients found in mushroom play an important role in carrot root development. According to Athanse et al., (2015) adding organic amendments increased the total porosity which decreased bulk density thereby increasing root penetrability. In return, it improved nutrient exploration by plants for better growth and yield.

\section{Weight of marketable roots}

The weight of marketable roots was significantly affected by different irrigation frequency and combined use of organic and inorganic fertilizers. Highest mean was produced by plants in T2 (801.67 gm) followed by T6 (482.67 gm), T3 (474.0 gm), T7 (303.33 gm), T4 (158gm), T1 (118.30 $\mathrm{gm})$, T8 (40 gm), and T5 (20 gm) (Table 6). Findings of this study is supported by the findings of Athanse et al., (2015) conforming that the total porosity will be enhanced when organic amendments is added. In the same view, Babu et al., (2014) believed that recycling residue in the soil is important techniques in improving soil fertility and biological properties.

\section{Number of non-marketable roots}

As shown in Table 6 irrigation frequencies and combined used of organic soil amendment and inorganic fertilizers significantly affect the number of non-marketable roots. Plants with recorded highest number of non-marketable roots were in T5 and have a mean of 9, while the lowest were those plants in T2 and T6 with a mean of zero (Table 6). The production on the highest number of non-marketable roots was related to smaller sizes on the diameter of carrots.

\section{Weight of non-marketable roots}


The interaction of irrigation frequency and fertilizer sources on the weight of non-marketable carrot roots are shown in Table 5. Plants in T1 significantly had highest non-marketable root weight followed by those in T4, T8, T5, T6, T7, T3 and T2 in descending order (Table 6).

\section{Yield (ton/ha)}

Based on the findings of this study, carrot yield was significantly affected by the interaction of irrigation frequency and combined use of organic soil amendments and inorganic fertilizers. Root yield in T2 significantly differed from those in T6, T3, T7, T4, T1, T8 and T8 and T5 with a corresponding means of $26.88,25.82,17.88,11.42,10.90,6.58, \& 4.02$ tons/ha, respectively. The significant result on the yield in ton $\mathrm{ha}^{-1}$ was contributed by significant result on the number and weight of marketable roots. Adeleye et al., (2010) cited by Jeptto et al., (2013) stressed out soil conditions will be enhanced with the use of organic manures that lead to carrot root expansion and development.

Table 6: Mean data on the effect of different irrigation frequency and combined use of organic soil amendments and inorganic fertilizer to the growth and yield of carrot.

\begin{tabular}{|c|c|c|c|c|c|c|c|c|}
\hline \multirow{2}{*}{$\begin{array}{l}\text { PARAMETE } \\
\text { RS }\end{array}$} & \multicolumn{8}{|c|}{ Treatment combinations $(\mathrm{T})$} \\
\hline & \multicolumn{4}{|c|}{$\begin{array}{l}\text { Irrigation frequency at } 2 \text { days interval } \\
\text { (F1) }\end{array}$} & \multicolumn{4}{|c|}{$\begin{array}{l}\text { Irrigation frequency at } 4 \text { days interval } \\
\text { (F2) }\end{array}$} \\
\hline $\begin{array}{l}\text { 1. Growth } \\
\text { 1.a. length of } \\
\text { leaves }(\mathrm{cm})\end{array}$ & \multirow{2}{*}{$\begin{array}{l}\text { Inorgan } \\
\text { ic } \\
\text { fertilize } \\
\mathrm{r} \\
\text { (S0) } \\
\text { T1 }\end{array}$} & \multirow{2}{*}{\begin{tabular}{|l} 
Mushro \\
om \\
spent \\
(S1) \\
T2
\end{tabular}} & \multirow{2}{*}{$\begin{array}{l}\text { Chick } \\
\text { en } \\
\text { dung } \\
\text { (S2) } \\
\text { T3 }\end{array}$} & \multirow{2}{*}{\begin{tabular}{|l} 
Sunflo \\
wer \\
(S3) \\
\\
T4
\end{tabular}} & \multirow{2}{*}{$\begin{array}{l}\text { Inorga } \\
\text { nic } \\
\text { fertiliz } \\
\text { er } \\
\text { (S0) } \\
\text { T5 }\end{array}$} & \multirow{2}{*}{$\begin{array}{l}\text { Mushro } \\
\text { om } \\
\text { spent } \\
\text { (S1) } \\
\text { T6 }\end{array}$} & \multirow{2}{*}{$\begin{array}{l}\text { Chick } \\
\text { en } \\
\text { dung } \\
\text { (S2) } \\
\text { T7 }\end{array}$} & \multirow[t]{2}{*}{$\begin{array}{l}\text { Sunflow } \\
\text { er (S3) } \\
\text { T8 }\end{array}$} \\
\hline & & & & & & & & \\
\hline $\begin{array}{l}31 \text { days after } \\
\text { emergence } \\
\text { (DAE) }\end{array}$ & $2.92 \mathrm{a}$ & $9.01 \mathrm{a}$ & $6.41 \mathrm{a}$ & $4.38 \mathrm{a}$ & $2.96 \mathrm{a}$ & $8.90 \mathrm{a}$ & $5.08 \mathrm{a}$ & $2.96 \mathrm{a}$ \\
\hline $38 \mathrm{DAE}$ & $5.73 a$ & $15.92 \mathrm{a}$ & $\begin{array}{l}11.92 \\
\mathrm{a}\end{array}$ & $8.90 \mathrm{a}$ & $5.78 \mathrm{a}$ & $15.55 \mathrm{a}$ & $10.18 \mathrm{a}$ & $6.81 \mathrm{a}$ \\
\hline $52 \mathrm{DAE}$ & $12.80 \mathrm{a}$ & $36.10 \mathrm{a}$ & $\begin{array}{l}28.63 \\
\mathrm{~b}\end{array}$ & $17.33 \mathrm{~d}$ & $12.87 \mathrm{e}$ & $33.53 \mathrm{ab}$ & $23.17 \mathrm{c}$ & $13.20 \mathrm{e}$ \\
\hline $66 \mathrm{DAE}$ & $21.87 \mathrm{de}$ & $52.63 a$ & $\begin{array}{l}45.10 \\
\mathrm{~b}\end{array}$ & $28.53 \mathrm{~d}$ & $20.63 e$ & $46.27 \mathrm{ab}$ & $36.57 \mathrm{c}$ & $22.53 \mathrm{de}$ \\
\hline $80 \mathrm{DAE}$ & $39.58 \mathrm{~cd}$ & $59.93 a$ & $\begin{array}{l}56.34 \\
\mathrm{a}\end{array}$ & $\begin{array}{l}40.40 \mathrm{c} \\
\mathrm{d}\end{array}$ & $21.55 d$ & $52.87 \mathrm{ab}$ & $\begin{array}{l}46.20 \\
\mathrm{bc}\end{array}$ & $35.52 d$ \\
\hline $88 \mathrm{DAE}$ & $\begin{array}{l}42.23 c d \\
e^{-}\end{array}$ & $62.50 \mathrm{a}$ & $\begin{array}{l}58.55 \\
\mathrm{a}\end{array}$ & $\begin{array}{l}45.06 \mathrm{c} \\
\mathrm{d}\end{array}$ & $34.43 e$ & $55.25 \mathrm{ab}$ & $\begin{array}{l}49.25 \\
\mathrm{bc}\end{array}$ & 39.06de \\
\hline $\begin{array}{l}\text { 1.b.Number } \\
\text { of leaves }\end{array}$ & $9.78 \mathrm{a}$ & $9.23 \mathrm{ab}$ & $\begin{array}{l}9.61 \mathrm{a} \\
\mathrm{b}\end{array}$ & $7.43 \mathrm{~b}$ & $8.46 \mathrm{ab}$ & $9.97 \mathrm{a}$ & $\begin{array}{l}8.43 \mathrm{a} \\
\mathrm{b}\end{array}$ & $8.77 \mathrm{ab}$ \\
\hline $\begin{array}{l}2 \text { Yield and } \\
\text { yield } \\
\text { components }\end{array}$ & & & & & & & & \\
\hline $\begin{array}{l}\text { 2.a.Diameter } \\
\text { of root }((\mathrm{cm})\end{array}$ & $1.06 \mathrm{a}$ & $3.12 \mathrm{a}$ & $2.43 a$ & $1.47 a$ & $0.79 \mathrm{a}$ & $2.70 \mathrm{a}$ & $2.03 a$ & $1.45 a$ \\
\hline $\begin{array}{l}\text { 2.b. Length of } \\
\operatorname{root}(\mathrm{cm})\end{array}$ & $12.72 \mathrm{a}$ & $15.77 \mathrm{a}$ & $\begin{array}{l}15.83 \\
\mathrm{a}\end{array}$ & $12.01 \mathrm{a}$ & $11.78 \mathrm{a}$ & $14.17 \mathrm{a}$ & $13.87 \mathrm{a}$ & $10.73 \mathrm{a}$ \\
\hline $\begin{array}{l}\text { 2.c. Number } \\
\text { marketable } \\
\text { root }\end{array}$ & $5.00 c$ & $10.00 \mathrm{a}$ & $9.00 \mathrm{a}$ & $5.33 b c$ & $1.00 \mathrm{~d}$ & $10.00 \mathrm{a}$ & $\begin{array}{l}8.30 \mathrm{a} \\
\mathrm{b}\end{array}$ & $2.00 \mathrm{~d}$ \\
\hline $\begin{array}{l}\text { 2.d. Weight of } \\
\text { marketable } \\
\text { root }(\mathrm{g})\end{array}$ & $118.30 \mathrm{e}$ & $801.67 \mathrm{a}$ & $\begin{array}{l}474.0 \\
0 \mathrm{~b}\end{array}$ & $\begin{array}{l}158.00 \\
\text { de }\end{array}$ & $20.00 \mathrm{e}$ & $482.67 \mathrm{~b}$ & $\begin{array}{l}303.3 \\
3 c d\end{array}$ & $40.00 \mathrm{e}$ \\
\hline 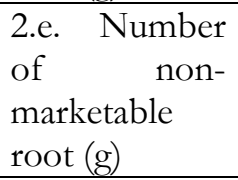 & $5.00 \mathrm{bc}$ & $0.00 \mathrm{e}$ & $\begin{array}{l}1.00 \mathrm{~d} \\
\mathrm{e}^{-1}\end{array}$ & $\begin{array}{l}4.67 \mathrm{bc} \\
\mathrm{d}\end{array}$ & $9.00 \mathrm{a}$ & $0.00 \mathrm{e}$ & $3.67 \mathrm{e}$ & $8.00 \mathrm{ab}$ \\
\hline $\begin{array}{l}\text { 2.f. Weight of } \\
\text { non- } \\
\text { marketable }\end{array}$ & $88.33 a$ & $0.00 \mathrm{c}$ & $\begin{array}{l}25.00 \\
\mathrm{bc}\end{array}$ & $\begin{array}{l}70.33 \mathrm{a} \\
\mathrm{b}\end{array}$ & $\begin{array}{l}59.00 \mathrm{a} \\
\mathrm{b}\end{array}$ & $55.00 \mathrm{ab}$ & $\begin{array}{l}54.33 \mathrm{a} \\
\mathrm{b}\end{array}$ & $68.00 \mathrm{ab}$ \\
\hline
\end{tabular}




\begin{tabular}{|l|l|l|l|l|l|l|l|l|}
\hline root $(\mathrm{g})$ & & & & & & & \\
\hline $\begin{array}{l}\text { 2.g. Yield } \\
\text { (ton/ha) }\end{array}$ & $10.90 \mathrm{de}$ & $40.08 \mathrm{a}$ & $\begin{array}{l}25.82 \\
\mathrm{bc}\end{array}$ & $11.42 \mathrm{~d}$ & $4.02 \mathrm{~d}$ & $26.88 \mathrm{~b}$ & $\begin{array}{l}17.88 \\
\mathrm{~b}\end{array}$ & $6.58 \mathrm{e}$ \\
\hline
\end{tabular}

* Means within a row bearing different letters are significantly different $(\mathrm{P}<0.05$. $)$

\section{Conclusion}

Giving consideration on the results of the study, it can be concluded that the use of organic soil amendments in combination of inorganic fertilizer and the frequency of irrigation on carrot production, T2 mushroom spent with irrigation frequency found as the best practice in growing carrot.

\section{References}

Ali, M. K., Barkotulla, M. A. B., Alam, M. N., \& Tawab, Kh. A. (2006). Effect of nitrogen levels on yield and yield contributing characters of three varieties of carrot. Pakistan Journal of Biological Sciences, 9(1), 553-557.

Ardiles, D., Campos, J., Fisher, S., \& Quezada, C. (2011) Water requirements and water use efficiency of carrot under drip irrigation in haploxer and soil. Journal of Soil Science Plant Nutrition, 11 (1), 16-28.

Sylvestre, H., Constance, U., Esdras, N., \& Athanase, N. (2015). Effect of poultry manure and NPK (17-1717) on the growth and yield of carrot in Rulindo. International Journal of Novel Research in Life Sciences. 2(1), 42-48.

Babu,S., Rana, D. S., Yadav, G. S., Singh, R., \& Yadav, S. K. (2014). A Review on Recycling of Sunflower Residue for Sustaining Soil Health. International Journal of Agronomy, 2014, 1-7.

Bjanadottir, A. (2015). Carrots 101: Nutrition Facts and Health Benefit. Retrieved from https://www.healthline.com/nutrition/foods/carrots.

Boateng, P. Y., Dawuda, M. M., Hemeng, O. B., and Nyarko, G. (2011). Growth and yield response of carrot (Daucuscarota L.) to different soil amendments and spacing. Journal Science and Technology, 31(2), 1-18.

Bonato, S., Gobbi, V., Nicoletto, C., Zanin, G. (2016). Spent mushroom substrate as organic fertilizer: Vegetable organic trials. Acta horticulture, 1146, 49-56.

Mbatha, A. N., Ceronio, G., \& Coetzer, G. (2013). Response of carrot (Daucuscarota L.) yield and quality to organic fertiliser. South African Journal of Plant and Soil, 31(1), 1-6.

David, J. G. and Whiting, D. (2013). Choosing a Soil Amendment. Retrieved from http://extension.colostate.edu/topic-areas/yard-garden/choosing-a-soil-amendme nt/.

De Lannoy, G. (2001). Carrot. In R.H. Raemaekers(ed.) Crop production in Tropical Africa. Directorate General for International Corporation, Brussels, Belgium, 480- 485.

Gillespie, R. N., and Reid, J. B. (2017). Yield and quality responses of carrots (Dancuscarota L.) to water deficits. New Zealand Journal of Crop and Horticultural Science. 45(4), 299-312.

Gesine, C. M.., Engelbrecht, G. M. And Mbatha, N. (2014). Response of carrot (Daucuscarota L.) yield and quality to organic fertiliser. South African Journal of Plant and Soil.

Grant, B. L. (2018). Deformed Carrots: Reasons For Distorted Carrots and How To Fix A Carrot Deformity Carrots. Retrieved from https://www.gardeningknowhow.com/edible/vegetables/carrot/fix-deformedcarrots.htm

Jeptoo, A., Aguyoh, J. N. \& Saidi, M. (2013). Tithonia manure improves carrot yield and quality. Global Journal of Biology, Agriculture and Health and Sciences. 2(4), 136-142.

Kiran, M., Jilani, M., Waseem, K., \& Marwat S. (2016). Response of Carrot (Daucuscarota L.) Growth and Yields to Organic Manure and Inorganic Fertilizers. American-Eurasian Journal of Agriculture \& Environmental Sciences, 16 (6), 1211-1218.

Leschmann, T. (2017). What Is Soil Amendment? Retrieved from https://www.gardenguides.com/119805-soilamendment.html.

Neilsen, G. H., Hogue, E. J., Neilsen, D. and Zebarth, B. J. (1998). Evaluation of organic wastes as soil amendments for cultivation of carrot and chard on irrigated sandy soils. Canadian Journal Soil Sciences, 78, 217-225.

Prince, R. (2018). Irrigating carrots for profit and environmental management.Food and Agriculture. Retrieved from https://www.agric.wa.gov.au/water-management/irrigating-carrots-profit-and-environmentalmanagement?nopaging $=1$

Rose, L. (2008). Soil \& Climate Requirement for Carrot Production. Retrieved from http://homeguides.sfgate.com/soil-climate-requirement-carrot-production-37802.html.

Seaman, A. (2016). Production guide for organic carrots for processing. New York State Integrated Pest Management Program, Cornell University, New York State Agricultural Experiment Station, Geneva, NY, p-10.

Seljasen, R., Kristinsen, H. L., Lauridsen, C., Wyss, G. S., Kretzschmar, U., Berlouez-Aragon, I., \& Kahl, J. (2013). Quality of carrots as affected by pre-and postharvest factors and processing. Journal of Sciences in Food Agriculture, 93(11), 2611-26. 
Stuart, G. U. (2015).Wild sunflower: Potential as Organic Foliar Fertilizer. Retrieved from http://www.stuartxchange.org/WildSunflower.html

Sunassee, S. (2002). Use of poultry litter for vegetable production. Food and Agricultural Research Council, Reduit, Mauritius, pp. 259- 263. 